\title{
What Matters in Business Incubation? \\ A Literature Review and a Suggestion for Situated Theorising
}

\begin{abstract}
Purpose - The purpose of this paper is twofold: first, to provide a critical assessment of the literature on business incubation effectiveness and second, to submit a situated theoretical perspective on how business incubation management can provide an environment that supports the development of incubatee entrepreneurs and their businesses.
\end{abstract}

Design / methodology / approach - The paper provides a narrative critical assessment of the literature on business incubation effectiveness. Definitional issues, performance aspects and approaches to establishing critical success factors in business incubation are discussed. Business incubation management is identified as an overarching factor for theorising on business incubation effectiveness.

Findings - The literature on business incubation effectiveness suffers from several deficiencies, including definitional incongruence, descriptive accounts, fragmentation and lack of strong conceptual grounding. Notwithstanding the growth of research in this domain, understanding of how entrepreneurs and their businesses develop within the business incubator environment remains limited. Given the importance of relational, intangible factors in business incubation and the critical role of business incubation management in orchestrating and optimising such factors, it is suggested that theorising efforts would benefit from a situated perspective.

Originality / value - The identification of specific shortcomings in the literature on business incubation highlights the need for more systematic efforts towards theory building. It is suggested that focusing on the role of business incubation management from a situated learning theory perspective can lend itself to a more profound understanding of the development process of incubatee entrepreneurs and their firms. Theoretical propositions are offered to this effect, as well as avenues for future research.

Keywords - Business incubation management, Business incubation effectiveness, business incubation success factors, business incubation performance, situated learning theory

Paper type - Conceptual Paper 


\section{Introduction}

Small businesses are fundamentally important to innovation, productivity, competition and employment generation, as well as social cohesion (Birch, 1979; Storey, 1994; Timmons, 1994; Roure, 1997; Jack and Anderson, 1999; URS, 2010; BIS, 2012). Consequently, the last 30 years have seen a shift in entrepreneurship development policy from the periphery to centre-stage (Sondakh and Rajah, 2006; EC, 2010; Lewis et al., 2011). Within this context, business incubation has been used as an entrepreneurship development policy instrument to increase the pool of new firms and deal with their needs in the early, vulnerable stage of their existence (Grimaldi and Grandi, 2005; McAdam and Marlow, 2007; Dee et al., 2011; UKBI, 2012). In essence, the concept of business incubation refers to a concerted, systematic effort to nurture new firms in the early-stage of their activity in a controlled environment. As a dynamic process, it offers a combination of infrastructure, development-support processes and expertise needed to safeguard against failure and steer incubatee firms into a growth path.(Tötterman and Sten, 2005; NESTA, 2008; UKBI, 2012).

Since the first business incubator, the Batavia Industrial Centre in New York in 1959, the concept and its manifestation into physical infrastructure rapidly took root in America and then around the world. Its international appeal has been fuelled by a number of studies that indicated the potential of business incubation as a vehicle for economic development (Smilor and Gill, 1986; Lumpkin and Ireland, 1988; Campbell, 1989; Bearse, 1993; NBIA, 1996; OECD, 1999; Lee and Osteryoung, 2004; Peters et al., 2004; Bergek and Norrman, 2008; URS, 2010; UKBI, 2012). However, despite this surge of interest in academic and policy making circles in many developed and developing countries, there is still no consensus over what business incubation is, or should be, and which factors contribute to successful business incubation. Moreover, the extent to which business incubation adds value has been questioned (Rouach et al., 2010; Lewis et al., 2011; Bruneel et al., 2012).

The aim of this paper is twofold. First, to critically assess the extant literature on business incubation effectiveness and second, to suggest a situated theoretical perspective on how business incubation management can provide an environment that supports the development of incubatee entrepreneurs and their firms. The paper is structured in four sections. Following this introduction, the second section discusses definitional issues surrounding 
business incubation and business incubation effectiveness, as well as the implications of the way that these concepts are defined. Moreover, it delineates the factors that have been identified as crucial for successful business incubation and the challenges relating to this exercise. Drawing on the identification of business incubation management as an overarching success factor, the third section submits a theoretical perspective on business incubation management, incubatee entrepreneurial development, and firm growth. The final, section concludes the paper and offers avenues for future research

\section{Business Incubation and Effectiveness}

\section{Defining Business Incubation}

Considering the literature on business incubation, it can be broadly classified into two domains: academic-based and industry-based. Scholars have primarily focused on the evolution of incubation and/or on a specific element of the process (e.g. Tötterman and Sten, 2005; Hughes et al., 2007; Ascigil and Magner, 2009). Incubator associations like UK Business Incubation (UKBI) and the National Business Incubation Association (NBIA), as well as various consultancy firms have centred their attention on incubators and the positive impact they have on new start-ups and on the economic environment, through evaluation studies and identification of best practice (Dee et al., 2011). Nonetheless, there is still no universally accepted definition of business incubation and incubator Table 1 below displays in chronological order commonly adopted definitions of business incubation/incubator in the literature. 
Table 1: Commonly Adopted Definitions of Business Incubation/Incubator

\begin{tabular}{|c|c|}
\hline Author(s) & Definition \\
\hline $\begin{array}{l}\text { Plosila and Allen } \\
\text { (1985) }\end{array}$ & $\begin{array}{l}\text { "A small business incubator is a facility which promotes the early stage } \\
\text { development of a for-profit enterprise." }\end{array}$ \\
\hline $\begin{array}{l}\text { Allen and Rahman } \\
(1985: 12)\end{array}$ & $\begin{array}{l}\text { "A small business incubator is a facility that aids the early-stage growth of } \\
\text { companies by providing rental space, shared office services, and business consulting } \\
\text { assistance." }\end{array}$ \\
\hline Albert (1986) & $\begin{array}{l}\text { "An enterprise incubator is a collective and temporary place for accommodating } \\
\text { companies which offer space, assistance and services suited to the needs of } \\
\text { companies being launched or recently founded." }\end{array}$ \\
\hline $\begin{array}{l}\text { Smilor and Gill } \\
\text { (1986) }\end{array}$ & $\begin{array}{l}\text { "The business incubator seeks to effectively link talent, technology, capital, and } \\
\text { know-how in order to leverage entrepreneurial talent and to accelerate the } \\
\text { development of new companies." }\end{array}$ \\
\hline $\begin{array}{l}\text { Allen and Bazan } \\
(1990)\end{array}$ & $\begin{array}{l}\text { "An incubator is a network or organisation providing skills, knowledge and } \\
\text { motivation, real estate experience, provision of business and shared services." }\end{array}$ \\
\hline $\begin{array}{l}\text { Allen and } \\
\text { McCluskey (1990) }\end{array}$ & $\begin{array}{l}\text { "An incubator is a facility that provides affordable space, shared office services and } \\
\text { business development assistance in an environment conducive to new venture } \\
\text { creation, survival and early stage growth." }\end{array}$ \\
\hline $\begin{array}{l}\text { Hackett } \\
(2004:\end{array}$ & $\begin{array}{l}\text { "A business incubator is a shared office-space facility that seeks to provide its } \\
\text { incubatees (i.e. portfolio- or client or tenant companies) with a strategic value- } \\
\text { adding intervention system (i.e. business incubation) of monitoring and business } \\
\text { assistance." }\end{array}$ \\
\hline $\begin{array}{l}\text { Hughes, Ireland and } \\
\text { Morgan (2007: } \\
155)\end{array}$ & $\begin{array}{l}\text { "A business incubator] is a facility that houses young, small firms to help them } \\
\text { develop quickly into competitive business." }\end{array}$ \\
\hline Eshun & $\begin{array}{l}\text { "A business incubator is an environment formally designed to stimulate the growth } \\
\text { and development of new and early stage firms by improving their opportunities for } \\
\text { the acquisition of resources aimed at facilitating the development and } \\
\text { commercialisation of new products, new technologies and new business models. } \\
\text { Business incubation is also a social and managerial process aimed at supporting the } \\
\text { development and commercialisation of new products, new technologies and new } \\
\text { business models." }\end{array}$ \\
\hline $\begin{array}{l}\text { UK Business } \\
\text { Incubation }\end{array}$ & $\begin{array}{l}\text { "Business incubation is a unique and highly flexible combination of business } \\
\text { development processes, infrastructure and people designed to nurture new and small } \\
\text { businesses by supporting them through the early stages of development and } \\
\text { change". }\end{array}$ \\
\hline $\begin{array}{l}\text { American National } \\
\text { Business Incubation } \\
\text { Association } \\
\text { NBIA }(2010: 1)\end{array}$ & $\begin{array}{l}\text { "A business incubator is a business support process that accelerates the successful } \\
\text { development of start-up and fledgling companies by providing entrepreneurs with an } \\
\text { array of targeted resources and services. These services are usually developed or } \\
\text { orchestrated by incubator management and offered both in the business incubator } \\
\text { and through its network of contacts. A business incubator's main goal is to produce } \\
\text { successful firms that will leave the programme financially viable and freestanding. } \\
\text { These incubator graduates have the potential to create jobs, revitalise } \\
\text { neighbourhoods, commercialise new technologies, and strengthen local and national } \\
\text { economies." }\end{array}$ \\
\hline $\begin{array}{l}\text { Entrepreneur } \\
(2014: 1)\end{array}$ & $\begin{array}{l}\text { 'Business Incubator is an organization designed to accelerate the growth and success } \\
\text { of entrepreneurial companies through an array of business support resources and } \\
\text { services that could include physical space, capital, coaching, common services, and } \\
\text { networking connections }\end{array}$ \\
\hline
\end{tabular}


Most studies consider business incubators as an entrepreneurship development tool for economic and social development; the underlying logic is that more successful start-ups would enhance innovation, job creation and social cohesion (Smilor and Gill, 1986; OECD, 1999; UKBI, 2009; Dee et al.., 2011; Lewis et al., 2011). Regardless of any emphasis on economic or social performance, business incubators are set to provide incubatees with affordable office space and a variety of support services both in-house and through external affiliates. However, beyond this broad-level, rudimentary consensus on what a business incubator is about, there are certain perennial definitional issues concerning the notions of 'business incubation' and 'business incubators'.

First, there is an issue with terminology adaptation. This relates to "...the repeated adaptation of the original business incubator concept in order to fit varying local needs and conditions" (Kuratko and LaFollette, 1987: 53). A case in point is the treatment of the virtual incubator, or 'incubator without walls' ((Nowak and Grantham, 2000; van Tilburg et al., 2002). Virtual incubation aims to deliver a range of support services (without a physical infrastructure) to incubatees who are located outside of an incubator. Although the goal is the same (i.e. to increase the likelihood of survival and growth of new firms), it does not provide entrepreneurs with physical infrastructure under a tenancy arrangement. Consequently, the notion of 'virtual incubator' has been challenged (Lewis, 2001).

Second, there is an issue with the multiplicity of the business incubation/incubator notion. This is illustrated by the interchangeable manner in which terms other than 'incubator' appear in the literature, but which nevertheless clearly refer to the same concept. These, include: 'research parks' (Danilov, 1971; Kang, 2004), 'enterprise centres' (Smilor, 1987), seedbeds' (Felsenstein, 1994), 'science parks', 'technopole' (Castells and Hall, 1994), (Gower and Harris, 1996; Gower et al., 1996; Westhead and Batstone, 1999; Ferguson and Olofsson, 2004; Hansson, 2007; Squicciarini, 2009), 'industrial parks' (Autio and Klofsten, 1998), 'innovation centres' (Smilor, 1987; Reid and Garnsey, 1997; UKBI, 2009), 'knowledge parks' (Bugliarello, 1998), 'business accelerator' (Barrow, 2001; UKBI, 2009), 'cold frames', 'hatcheries', 'hives', 'germinators', 'hubs', 'hot-desks', 'graduators', 'grow-on space', 'spokes', 'ideas labs', 'managed workspace', 'venture labs', 'business centres', 'fertilisators' (UKBI, 2009, 2012) and the 'networked incubator' (Hansen et al., 2000; Bøllingtoft and Ulhøi, 2005; McAdam and McAdam, 2006). Put another way, researchers 
have defined and referred to the term of business incubation/incubator over the years in many ways.

Finally, to make matters worse, the business incubation process is not precisely defined in many relevant studies. Hackett and Dilts (2004: 60) aptly refer to this as, “...[the] persistent tendency to not define the incubation process, or when defined to disagree on where and with whom the incubation process occurs". The above definitional issues often make it difficult to assess the business incubation industry's actual size in the UK and abroad, considering only genuine business incubators (as opposed to managed estates). Furthermore, such issues hinder generalisation of findings and theorising in the field of business incubation. Using typologies, such as the generational classifications (see for instance, Aerts et al., 2007; Bruneel, et al. 2012) ameliorates challenges relating to heterogeneity, but cannot solve the issue of definitional ambiguity entirely.

Figure 1: The Evolution of Business Incubators from first to third Generation

\begin{tabular}{|c|c|c|}
\hline $\begin{array}{l}\mathbf{1}^{\text {st }} \text { Generation } \\
\text { - Affordable space } \\
\text { - Shared facilities }\end{array}$ & $\begin{array}{l}\text { 2nd Generation } \\
\text { - Affordable space } \\
\text { - Shared facilities } \\
\text { - A variety of support } \\
\text { services } \\
\text { - Business advisory } \\
\text { services } \\
\text { - Networking }\end{array}$ & $\begin{array}{l}\text { 3rd Generation } \\
\text { - Affordable space } \\
\text { - Shared facilities } \\
\text { - A variety of support } \\
\text { services } \\
\text { - Business advisory } \\
\text { services } \\
\text { - Networking } \\
\text { - Proactive support } \\
\text { - Mentoring \& Coaching } \\
\text { - Business acceleration } \\
\text { - Network development }\end{array}$ \\
\hline 1980-1990 & $1991-2000$ & 2001-To date \\
\hline
\end{tabular}

Assessing the Effectiveness of Business Incubation

Researchers have used various indicators to assess the effectiveness of business incubation. For instance, Allen and McCluskey (1990) in their US study on 127 business incubators used three indicators: 'occupancy', 'jobs created' and 'firms graduated'. Phillips (2002), in line 
with Allen and McCluskey (1990), adopted another three indicators. These were 'tenant revenue', 'number of patent applications per firm' and 'number of discontinued businesses'. Later, Chan and Lau (2005) adopted nine indicators these were 'advantages from pooling resources', 'sharing resources', 'consulting services', 'positive effects from a higher public image,' 'networking advantages', 'clustering effects', 'geographic proximity', 'cost subsidies' and 'funding support'. Much of the literature draws on such indicators. Table 2 below provides a snapshot of the main success indicators used in the literature.

Table 2: Various Success Indicators/Measures Identified in the Literature

\begin{tabular}{|c|c|}
\hline $\begin{array}{l}\text { The Business Incubation } \\
\text { Programme Perspective }\end{array}$ & Indicative Literature \\
\hline $\begin{array}{l}\text { Business Incubator } \\
\text { Occupancy Rate/ } \\
\text { New firms supported }\end{array}$ & $\begin{array}{l}\text { Allen (1985); Allen and Rahman (1985); Smilor (1987); Campbell (1989); } \\
\text { Allen and McCluskey (1990); Phillips (2002); European Commission (2002); } \\
\text { Vanderstraeten, Witteloostuijn and Matthyssens et al. (2011); Al-Mubaraki and } \\
\text { Schrödi (2012); Al-Mubaraki and Wong (2011) }\end{array}$ \\
\hline Business Incubator Space & $\begin{array}{l}\text { Lalkaka and Shaffer (1999); European Commission (2002); Knopp (2007); Al- } \\
\text { Mubaraki and Schrödi (2012) }\end{array}$ \\
\hline Graduate Firms & $\begin{array}{l}\text { Udell (1990); Allen and McCluskey (1990); Mian (1997); European } \\
\text { Commission (2002); Philips (2002); UKBI (2004, 2009); Al-Mubaraki and } \\
\text { Wong (2011); Al-Mubaraki and Schrödi (2012) }\end{array}$ \\
\hline $\begin{array}{l}\text { Level of Funding Received } \\
\text { from Key Benefactors (this } \\
\text { includes, State, Industry } \\
\text { and University) }\end{array}$ & $\begin{array}{l}\text { Allen (1985); Mian (1997); European Commission (2002); UKBI (2009); } \\
\text { Wadhwani Foundation (2013) }\end{array}$ \\
\hline $\begin{array}{l}\text { Survival Rates of } \\
\text { Incubatees }\end{array}$ & $\begin{array}{l}\text { Allen and Levine (1986); Hisrich and Smilor (1988); Allen and McCluskey } \\
\text { (1990); Mian (1996, 1997); Westhead (1997); European Commission (2002); } \\
\text { Phillips (2002); Hackett and Dilts (2004); Ferguson and Olofsson (2004); } \\
\text { Knopp (2007); Schwartz and Göthner (2009) }\end{array}$ \\
\hline Sales Growth & $\begin{array}{l}\text { Allen and Levine (1986); Hisrich and Smilor (1988); Mian (1996, 1997); } \\
\text { Phillips (2002); Löfsten and Lindelöf (2002); European Commission (2002); } \\
\text { Ferguson and Olofsson (2004) Dettwiler et al. (2006); Chen (2009); } \\
\text { Vanderstraeten et al. (2011); Schwartz (2011); Barbero et al. (2012); Wadhwani } \\
\text { Foundation (2013) }\end{array}$ \\
\hline $\begin{array}{l}\text { Employment Growth } \\
\text { (Number of Jobs Created } \\
\text { by Incubatee Firms) }\end{array}$ & $\begin{array}{l}\text { Allen and McCluskey (1990); Udell (1990); Mian (1996, 1997); Löfsten and } \\
\text { Lindelöf (2002); European Commission (2002); Phillips (2002); Colombo and } \\
\text { Delmastro (2002); Dettwiler et al. (2006); Löfsten and Lindelöf (2002); } \\
\text { Amezcua (2010); Al-Mubaraki and Wong (2011); Vanderstraeten et al. (2011); } \\
\text { Schwartz (2011); Al-Mubaraki and Schrödi (2012);Barbero et al. (2012); } \\
\text { Wadhwani Foundation (2013) }\end{array}$ \\
\hline
\end{tabular}

Despite the growth of research in business incubation, there is no consensus on defining success in terms of quality and efficiency measures, nor on which indicators/variables have the greatest impact (Dee et al., 2011; UKBI, 2012). As Lalkaka (2001) pointed out a long 
time ago, stakeholder(s) expectations affect the indicators used to measure success and assess the effectiveness of business incubation. Different stakeholders have different objectives and therefore success measures and the type of data collected for one business incubator may not be the same for another (see for instance Hannon and Chaplin, 2003). For instance, in a university-based incubator, the incubator manager may consider high survival rate as the key criterion for success. However, from the university's point of view, unless this is accompanied by a high level of graduates employed, this alone may not be a satisfactory measure of effectiveness for the university. Moreover, relating to the difficulties involved in matching samples (groups of incubatees against control groups) in evaluative work, is the lack of standardisation in success measures and measurements, which makes effective evaluation a very difficult exercise. Moreover, it has been argued that the assessment of business incubation success needs to be broader than a set of statistical outputs; it should consider additional aspects of effectiveness, including 'soft' aspects of business incubation output (Voisey et al., 2006).

\section{Key Success Factors in Business Incubation}

As mentioned earlier, research on business incubation has employed different success criteria. Early studies on business incubation/incubators have focused primarily on individual or multiple-case studies, defining business incubators' physical facilities and establishing best practice in the industry (UKBI, 2009; Dee et al., 2011; Lewis et al., 2011). However, the majority of these studies suffer from two major shortcomings. First, they rarely define precisely what constitutes success. Second, even when they do, it is often hard to determine the degree of success, with local factors determining to a certain extent business incubation outcomes (UKBI, 2009; Dee et al., 2011). Furthermore, due to the small-scale nature of these studies we cannot generalise their findings to the population. Hence, although these studies can be inspiring and motivating to the industry, their value in terms of knowledge and insight leaves much to be desired.

Later, researchers focused their attention on identifying the key success factors in business incubation. Lumpkin and Ireland (1988) defined key success factors as "those dimensions of a firm's operations that are vital to its success". This includes the constituent elements of the 
business incubator's design and support arrangements (Autio and Klofsten, 1998). Key success factors then are essential in ensuring that incubatee firms are successful (survive and grow) and they must work well in combination with each other. Much of the literature draws on Smilor and Gill's (1986) seminal study on business incubation in America, almost 30 years ago, where they examined the effectiveness of the concept. From the results, Smilor and Gill (1986) identified ten critical success factors in business incubation. These are: onsite business expertise, access to financing and capitalisation, in-kind financial support, community support, entrepreneurial networks, entrepreneurial education, perception of success, selection process for tenants, ties with a university and a concise programme with clear policies, procedures and milestones. These findings highlighted a direct correlation between successful business incubation and the extent to which businesses incubators consciously implement each of these factors. It would appear that the more extensively these factors feature in a business incubator, the greater the likelihood of success for the incubatee firms.

Following Smilor and Gill's work, several studies extended the list of key factors to business incubation success (for an indicative literature, see table 3). These, for example, include the clarity of mission and objectives, the monitoring of the performance of business incubation, the sector specificity, the incubatee selection process, the graduation/exit processes, the proximity to a major university, the level and quality of management support, the extent of access to potential internal/external entrepreneurial networks, and last but not least, the competency of the incubator manager to configure hard and soft elements of the business incubation environment and shape the relational context within which incubatee entrepreneurs operate (for example, Udell, 1990; Lichtenstein, 1992; Goldberg and LaviSteiner, 1996; Lalkaka and Bishop, 1996; Autio and Klofsten, 1998; Rice, 2002; Hackett and Dilts, 2004, 2008; Lewis et al., 2011; UKBI, 2012).

As the literature in business incubation grew, the list of key success factors became longer and inconclusive. Table 3 below outlines the main key-factor domains highlighted by this stream of literature. 
Table 3: Key Success Factors in Business Incubation

\begin{tabular}{|c|c|}
\hline Key Success Factors & Indicative Literature \\
\hline $\begin{array}{l}\text { Incubatee Selection } \\
\text { Policy }\end{array}$ & $\begin{array}{l}\text { Smilor and Gill (1986); Merrifield (1987); Kuratko and LaFollette (1987); } \\
\text { Lumpkin and Ireland (1988); Autio and Klofsten (1998); Colombo and } \\
\text { Delmastro (2002); Wiggins and Gibson (2003); Hackett and Dilts (2004; 2008); } \\
\text { Peters, Rice and Sundararajan (2004); Lalkaka (2006); Buys and Mbewana } \\
\text { (2007); Aerts, Matthyssens and Vandenbempt (2007); Bergek and Norrman } \\
\text { (2008); infoDev (2009); OECD (2010); UKBI (2004, 2009, 2012); Dee, Livesey } \\
\text { and Gill 2011); Lewis, Harper-Anderson and Molnar (2011); Khalid, Gilbert } \\
\text { and Huq (2012) }\end{array}$ \\
\hline Exit/Graduation Policy & $\begin{array}{l}\text { Allen (1985); Campbell (1989); Markley and McNamara (1994); Mian (1996); } \\
\text { EC (2002); Hackett and Dilts (2004, 2008); Rothaermel and Thursby (2005); } \\
\text { Lalkaka (2006); Bergek and Norrman (2008); UKBI (2004, 2009, 2012) Bergek } \\
\text { and Norrman (2008); Patton, Warren and Bream (2009) infoDev (2009); OECD } \\
\text { (2010); Dee, Livesey and Gill (2011); Al-Mubaraki and Wong 2011; Lewis, } \\
\text { Harper-Anderson and Molnar (2011); Al-Mubaraki and Schrodi (2012); }\end{array}$ \\
\hline $\begin{array}{l}\text { Shared Office Space and } \\
\text { Resources }\end{array}$ & $\begin{array}{l}\text { Allen (1985); Hisrich and Smilor (1988); Mian (1997); European Commission } \\
\text { (2002); Rice (2002); Chan and Lau (2005); Dettwiler, Lindelöf and Löfsten } \\
\text { (2006)); infoDev (2009); OECD (2010); UKBI (2004, 2009, 2012); Dee, } \\
\text { Livesey and Gill (2011); Lewis, Harper-Anderson and Molnar (2011) Khalid, } \\
\text { Gilbert and Huq (2012) }\end{array}$ \\
\hline $\begin{array}{l}\text { Incubator Manager } \\
\text { Competences and } \\
\text { Relationship with } \\
\text { Incubatees }\end{array}$ & $\begin{array}{l}\text { Fry (1987); Allen and Bazan (1990); Udell (1990); Lichtenstein, 1992; Autio } \\
\text { and Klofsten (1998); Sherman (1999); Duff (2000); Rice (2002); Lalkaka } \\
\text { (2002); Hannon, (2005); Hackett and Dilts (2004, 2008); Dee, Livesey and Gill } \\
\text { (2011) }\end{array}$ \\
\hline $\begin{array}{l}\text { Support Services } \\
\text { - Management know- } \\
\text { how } \\
\text { - Advice on regulations } \\
\text { - Technology \& RD } \\
\text { support } \\
\text { - Networking (internal \& } \\
\text { external) } \\
\text { - Access to funding }\end{array}$ & $\begin{array}{l}\text { Campbell, Kendrick and Samuelson (1985); Allen (1985); Smilor and Gill } \\
\text { (1986); Kuratko and LaFollette (1987); Lichtenstein (1992); Rice (1993); Mian } \\
\text { (1997); Lee, Kim and Chun (1999); Lalkaka and Shaffer (1999); Hannon and } \\
\text { Chaplin (2001); Hansen, Chesbrough and Nohria (2000); Barrow (2001); Rice, } \\
\text { (2002); European Commission (2002); Hannon and Chaplin (2003); Wiggins } \\
\text { and Gibson (2003); Cammarata (2003); Hoang and Antoncic (2003); Hackett } \\
\text { and Dilts (2004); Lee and Osteryoung (2004); Peters, Rice and Sundararajan } \\
\text { (2004); Chan and Lau (2005); Phan, Siegel and Wright (2005); Rothschild and } \\
\text { Darr (2005); Bøllingtoft and Ulhøi (2005); Dettwiler, Lindelöf and Lofsten } \\
\text { (2006); Suk and Mooweon (2006); Lalkaka (2006); Buys and Mbewana (2007); } \\
\text { Knopp (2007); McAdam and McAdam (2008); Bergek and Norrman (2008); } \\
\text { Patton, Warren and Bream (2009); infoDev (2009); UKBI (2009, 2012); } \\
\text { Connell and Probert, (2010); OECD (2010); Xu (2010); Dee, Livesey,Gill and } \\
\text { Minshall (2011); Lewis, Harper-Anderson and Molnar (2011); Adlešič and } \\
\text { Slavec (2012); Al-Mubaraki and Schrödi (2012); Ebbers (2013) }\end{array}$ \\
\hline Monitoring Performance & $\begin{array}{l}\text { Smilor and Gill (1986); Mian (1997); European Commission (2002); Wiggins } \\
\text { and Gibson (2003); Hackett and Dilts (2004, 2008); Abetti, (2004); Lalkaka } \\
\text { (2006); UKBI (2009, 2012); Al-Mubaraki and Wong (2011); Dee, Livesey, Gill } \\
\text { and Minshall (2011); Khalid, Gilbert and Huq (2012) }\end{array}$ \\
\hline
\end{tabular}

Notwithstanding efforts to identify the factors that matter in successful business incubation, only a few relationships between success factors and measures have been tested, making it difficult to assess the significance of each factor (Dee et al., 2011; Lewis et al., 2011). To make matters worse, business incubators tend to differ considerably; not all successful 
incubators (by any measure of success) adhere to all key success factors and a factor that may be crucial for a given incubator may not be as significant for another.

A good part of this issue relates to Phan et al. (2005: 166) problematisation: "there is a failure to understand the dynamic nature [of business incubators] as well as that of the companies located in them...there is a lack of clarity regarding the performance of science parks and incubators which is associated with problems in identifying the nature of performance". There remains little conclusive evidence of what makes a successful business incubation programme and the question of how we should measure success remains elusive. This is not helped by a tendency in business incubation research to examine a population with a successbias. According to Honig and Karlsson (2007: 2), such studies have led to "over estimating success, failure to identify riskier strategies and mistakes, and an inability to learn from failure (e.g. learning from the many incubators that have failed)"”.

Notably, a review of the literature indicates a shift in emphasis from physical business incubation facilities and tangible aspects, to the business development process and less tangible elements (Dee et al., 2011; Bøllingtoft, 2012; Ebbers, 2013). By and large, this shift in emphasis is a manifestation of the realisation that although incubatee entrepreneurs tend to utilise infrastructure the most, "office services are easy to imitate, business support and networks are not; they are usually unique” (Bøllingtoft and Ulhøi, 2005: 280). This relates to the crucial notion of differential performance of business incubators in equipping incubatee entrepreneurs with business management know-how and access to the relevant people, information and resources (Karatas-Ozkan, Murphy and Rae, 2005; Hackett and Dilts, 2004, 2008). A number of studies suggest that business incubators can facilitate and actively support networking among incubatee entrepreneurs, as well as between incubatee entrepreneurs and other external stakeholders, through which business opportunities are identified and exploited (Hansen et al., 2000, Hackett and Dilts, 2004; Bøllingtoft and Ulhøi, 2005, Tötterman and Sten, 2005; McAdam and McAdam, 2006 and Schwartz and Hornych, 2008; Patton et al., 2009; Lewis et al., 2011; Adlešič and Slavec, 2012).

Nonetheless, limited attention has been paid to theory building in the field of business incubation, with much of the literature being exploratory and descriptive in nature or atheoretical (Hackett and Dilts, 2004, 2008). A host of theoretical perspectives have been 
suggested for investigating different aspects of business incubation including transaction cost economics (Williamson, 1975), theory of economic development through entrepreneurship (Brooks, 1986), network theory (Hansen et al., 2000), interdependent co-production modelling (Rice, 2002), and structural contingency theory (Ketchen et al., 1993). Yet, theorising about business incubation lacks coherency and despite a few notable exceptions (for example, McAdam and Marlow, 2007; Patton et al., 2009; Marlow and McAdam, 2012) literature in this field disregards the perspectives and characteristics of incubatee entrepreneurs. Hence, notwithstanding the growth of research in this domain since the early efforts to provide frameworks that link business incubation with the incubatee development process (Temali and Campbell, 1984; Campbell et al., 1985; Smilor, 1987), there is still a need to understand 'how' and 'why' incubatee firms grow in a business incubator environment, in processual and longitudinal mode.

Integral to the issue of theoretical development is the role of business incubation management in providing the incubatee entrepreneurs with business support, know-how and networking opportunities for entrepreneurial learning and development, as well as their ability to understand the entrepreneurs' point of view and build a relationship with them (Fry, 1987; Udell, 1990; Autio and Klofsten, 1998; Sherman, 1999; Rice, 2002). In fact several studies have specifically acknowledged the incubator manager as a key success factor in business incubation that impacts other success factors (Allen and Bazan, 1990; Lichtenstein, 1992; Duff, 2000; Lalkaka, 2002; Hackett and Dilts, 2004, 2008). However, ties between incubatee entrepreneurs and the incubator manager tend to be infrequent (Honig and Karlsson, 2007), and "attempts by incubator management to link their incubatee entrepreneurs with potential business partners or resource providers outside the incubator often do not lead to successful collaboration" (Ebbers, 2013: 17). This perhaps can be attributed to different approaches taken by business incubator managers. Some tend to play a more passive role as gatekeepers, while others perform an active intermediary role, bringing together incubatee entrepreneurs with academics, business support providers and funders (Lewis et al., 2011; UKBI, 2012).

Yet, the literature offers little in-depth investigation of the business incubation manager's role. Notwithstanding the significance of incubation management, our understanding of how it contributes to the development of incubatee entrepreneurial development and firm growth firms remains limited. Arguably, given that the business incubator manager is a 'leverage' 
factor, influencing most of the other key success factors related to different aspects of business support and networking, their role is a crucial part of the theory development puzzle. In the following section, a situated learning theoretical perspective (Brown and Duguid, 1998; Wenger, 1998, 2000) is advanced as an analytical lens, to examine the role of incubation management in the entrepreneurial development of their incubatees.

\section{Business Incubation Management through the Lens of Situated Learning Theory}

Situated learning theory (SLT) holds that learning and development takes place in communities of practice - a concept referring to people who actively pursue a common enterprise - and that "what is needed is not to create learning, but rather to create the circumstances that make learning empowering and productive" within such communities (Wenger 1998: 22). Entrepreneurial learning and development within communities of practice has recently received the attention of scholars (Hamilton, 2011; Jones et al., 2010; Theodorakopoulos et al., 2012; Theodorakopoulos et al., 2013). Although there has been some discontent with normative/prescriptive approaches to nurturing communities of practice (see for instance Contu and Wilmott, 2000, 2003; Roberts, 2006) the argument for nurturing such communities for entrepreneurial learning and development is gaining credence.

Closer to the subject of business incubation, Theodorakopoulos et al. (2012) and Theodorakopoulos et al. (2013) examine the efforts of intermediary organisations in effecting entrepreneurial learning and development by developing communities of practice. Drawing on situated learning theory (Brown and Duguid 1998, 2001; Wenger 1998, 2000; Wenger, McDermott and Snyder 2002; Brown 2004; Wenger 2010) they argue that entrepreneurial learning and development as enhanced possession and use of human, social and financial capital, within a community of growth-oriented owner-managers, is predicated largely on three factors. First, the strength of the community; second, the quality of its 'boundaries' (i.e. the spaces where the owner-manager community interface with other communities of practice); and third, the health of the communal identity, which allows for the creation of new meaning, learning and development. It is postulated that these three factors influence the extent of entrepreneurial learning and development within communities of growth-oriented owner-managers, through which business opportunities are identified and exploited. 
Conceivably, given that even in the absence of top-down facilitation by incubator managers colocation still leads to interaction and collaboration among incubatee entrepreneurs (Bøllingtoft, 2012), the latter constitute an incubated community of 'growth-oriented' practice. The three key factors that influence the quality of such a community are discussed below.

\section{Community Strength}

The strength of a community of practice refers to how well members of that community engage and socially participate in the community's efforts toward the achievement of a common purpose, for instance business growth in this case. It also relates to how well a community of practice can coordinate perspectives, interpretations and actions so that higher goals are realised. Advocates of SLT have put forward community membership, events, and artefacts as design elements for strengthening a community and its potential for learning and development (Brown and Duguid 1998, 2001; Wenger 1998, 2000; Brown 2004; Wenger 2010). Membership must have critical mass to build momentum but not be too wide to dilute focus. It should also have the right structure so that the community gains legitimacy. Events that bring the community together, such as formal and informal meetings, help its members develop an identity. Artefacts, such as agendas, methodologies, plans, tools and discourses provide a community with a shared repertoire of resources, which help it align itself, deepen commitment and maintain momentum. Importantly, brokering relationships facilitate connectivity between its members. Brokers, acting as conduits amongst members, can have a significant input into the development of a community of practice by influencing the formation of a balanced structure, the design of effective events and the formation of potent artefacts (Wenger 2000; Brown and Duguid 2001). In that respect, conceivably, business incubation management can play a brokering role. Based on the above discussion, the following theoretical propositions are advanced:

\section{Proposition 1:}

Business incubation management for developing the incubated community's entrepreneurial competences relating to accessing, enhancing, and using human, social and financial capital 
involves the nurturing of an incubated community of growth-oriented entrepreneurs, via brokering amongst them.

Proposition 1a:

Business incubation management entails forming a balanced membership structure, organising events that bring the incubated community members and other external stakeholders together, and expressing 'know-how' in a way that is understood by the incubatee entrepreneurs.

Proposition 1b:

Business incubation management requires the shaping of potent artefacts that promote the development of entrepreneurial competences in the incubated community.

\section{Identity health}

The development of entrepreneurial competences goes hand in hand with the development of communal identity, i.e. entrepreneurial development is anchored in a social 'home' (Brown and Duguid 1998, 2001; Wenger 1998, 2000). According to SLT, identities are not an abstract idea, such as a personality trait or an ethnic category, but a lived experience of belonging to communities of practice - in this case an incubated community of growthoriented entrepreneurs. Healthy identities are strong enough to unite community members, without restricting their involvement in community activities and in negotiation for development of meaning. A healthy identity is empowering rather than marginalising. Importantly, it allows for generative learning, i.e. the creation of new meaning when community members face notions that counter their past experiences and challenge received wisdom. Drawing on Wenger $(1998,2000)$, Theodorakopoulos et al. $(2012,2013)$ refer to these identity dimensions as connectedness (i.e. uniting members), expansiveness (i.e. allowing for consideration of new perspectives) and effectiveness (i.e. enabling unrestricted participation and action) and argue that it is the combination of these dimensions that is significant in entrepreneurial learning and development. Following from this, the following theoretical propositions are submitted: 


\section{Proposition 2:}

Effective business incubation is predicated on the potential of management to nurture a healthy incubated community identity. This entails the development of a communal identity that sufficiently combines the three key dimensions of connectedness, expansiveness and effectiveness.

\section{Proposition 2a:}

Effective business incubation requires the formation of a membership structure that is not too heterogeneous (for instance, attracting incubatees from related industrial sectors) and the hosting of events that provide a home for the incubated community, so that its members connect with and learn from each other (identity connectedness) and are receptive to 'knowhow' relating to different perspectives (identity expansiveness).

\section{Proposition 2b:}

Fostering entrepreneurial learning in the incubated community and developing its entrepreneurial competences (identity effectiveness) is also influenced by the orientation of stakeholders involved in the governance of a business incubator and in exchanges with its incubated community.

\section{Boundary Space Quality}

The quality of the boundary spaces within which members of different communities of practice interact socially is instrumental in negotiating meaning and generating new perspectives, learning new competences and developing as professionals - in this case growth-oriented entrepreneurs. Wenger $(1998,2000)$ argues that the quality of boundary spaces - i.e. their effectiveness in connecting different communities of practice - is characterised by three dimensions: coordination, transparency and negotiability. Coordination refers to the extent to which boundary processes can be interpreted in different practices in a way that enables coordination. Transparency, relates to the degree to which the rationale underlying the practices involved becomes evident. Negotiability refers to the room for negotiation allowed between the perspectives of different practices interfacing in a boundary space. For instance, events where the incubated community of entrepreneurs 
interface with other stakeholders, such as academics, business support providers and potential buyers, should provide the details that are important to the practices of these stakeholders, but without burdening each other with unnecessary detail (enabling coordination). They should also afford windows into the logic underpinning the exchange process amongst the incubated community and other stakeholders (maximising transparency).

Coordination and transparency are determined by the presence of intelligible boundary objects and conducive boundary encounters. The latter provide direct exposure to the practices involved and are influenced by the effectiveness of brokers (Theodorakopoulos et al., 2012, 2013). That is, mediators should have a good understanding of the interfacing communities of practice. In this case, business incubation managers should have a good understanding of their incubating businesses and other engaging stakeholders, so that boundary encounters are conducive to entrepreneurial development and boundary objects are intelligible for the incubating community members that are involved in boundary spanning. Based on the above discussion, the following theoretical propositions are advanced:

\section{Proposition 3:}

Business incubation management that seeks to enable the entrepreneurial development of the incubated community represents a special form of brokerage that enables the incubatees' entrepreneurial learning and development through meaningful interaction with various stakeholders, including academics, business support providers, funders and potential buyers.

\section{Proposition 3a:}

The effectiveness of business incubation is predicated on the potential of management as brokers in creating generative boundary encounters within the incubated community, but also amongst the incubated community and the communities of external stakeholders.

\section{Proposition 3b:}

The effectiveness of business incubation is predicated on the potential of management as brokers in creating intelligible boundary objects, as well as in clarifying the boundary objects formed by external stakeholders, such as business plan templates and documents that set out $R \& D$ requirements, quality standards and supply requirements. 


\section{Conclusion and Avenues for Future Research}

Business incubation is regarded as an entrepreneurship development tool for promoting innovation, economic growth and employment generation. The substantial proliferation of business incubators around the world over the last three decades has been paralleled by a growing body of research in this domain. This paper contributes to the literature on business incubation in two ways. First, it provides a critical assessment of the literature on business incubation effectiveness and highlights certain perennial issues. Second, it offers a situated theoretical perspective for better understanding how business incubation management can foster the development of incubatee entrepreneurs and their firms.

A critical assessment of the literature reveals that notwithstanding the large number of studies in this field, there is still a lack of a comprehensive framework for assessing the effectiveness of business incubation. The heterogeneity of business incubators, definitional incongruence, and a wide variety of criteria for assessing the effectiveness of business incubation makes it difficult to establish the extent to which business incubators add value and what has the greatest impact for successful business incubation. Numerous studies in the literature have attempted to identify a set or bundle of key success factors and best practices for improving the performance of business incubators. Conventionally, the tangible elements of business incubators' resources have been applied as indicators of success but over the years emphasis has been shifted onto intangible factors and social aspects of business incubation, such as entrepreneurial networking, mentoring and coaching, which enhance possession, access and use of different forms of capital - social, human and financial. Yet, despite this shift of attention to more intangible factors of business incubation, it is evident that there are still significant gaps in our understanding of how business incubation management can support the entrepreneurial development of their incubatees. Part of the problem is that the bulk of research in the field of business incubation remains anecdotal, excludes the perspective of the incubatee, and suffers from informal research design and/or a limited theoretical focus.

To address these shortcomings, it is argued that future research needs to rebalance focus on research questions relating to 'what' and research questions addressing 'how' and 'why' a business incubation process leads to specific outcomes. To this effect, given the importance of the aforementioned intangible characteristics of business incubation and the pivotal role of 
the business incubation management, it is postulated that a situated learning theoretical perspective can enhance our understanding of how an environment that addresses the developmental needs of incubatee entrepreneurs and their firms can be nurtured. Specifically, it is maintained that future research should focus on how business incubation management can nurture incubated communities of growth-oriented tenants, in which entrepreneurial learning and development takes place. Drawing on situated learning theory, theoretical propositions are offered to this effect. Following this logic, entrepreneurial learning and development is seen as the building of capacity to identify and exploit business opportunities, underpinned by enhanced possession, access and use of human, social and financial capital, within incubated growth-oriented communities. This in turn is considered as being integrally linked to firm survival, growth and innovation at different levels, both organisational and interorganisational. Put another way, the entrepreneurial development of incubated communities of tenants impacts positively their firms individually and collectively and involves a host of engaging external stakeholders, such as academics, business support providers, funders, and various supply chain agents.

Ethnographic research informed by the theoretical propositions advanced in this paper, undertaken in a way that engages key structures and actors involved in business incubation, including the incubatee entrepreneurs, holds a great promise. Such research should be processual and longitudinal. It should consider institutional forces that enable or impede entrepreneurial learning and development within incubated communities of growth-oriented entrepreneurs. It should also examine different aspects of power relations and political activity in the business incubation process.

\section{Acknowledgments}

Thanks are due to the ESRC for supporting the project on which this work is based (ES/J001538/1). We would also like to thank the anonymous referees, as well as Professor Harry Matlay for his comments on an earlier version of this paper. 


\section{References}

Abetti, P.A. (2004), 'Government-supported incubators in the Helsinki region: Infrastructure, results and best practice', Journal of Technology Transfer 29 (1), 19-40.

Adlešič, R.V. and Slavec, A. (2012), 'Social capital and business incubators performance', Economic and Business Review, 14 (3), 201-222.

Aerts, K., Matthyssens, P., and Vandenbempt, K. (2007), 'Critical role and screening practices of European business incubators', Technovation 27 (5), 254-267.

Albert, P. (1986), 'Enterprise incubators - An initial diagnosis', Revue Francaise de Gestion Sep/Oct.

Allen, D. (1985), 'Business incubators: Assessing their role in enterprise development', Economic Development Commentary 9 (4), 3-8.

Allen, D. and Bazan, E. (1990), Value Added Contribution of Pennsylvania's Business Incubators to Tenant Firms and Local Economies, State College Pennsylvania, Appalachian Regional Commission and the Pennsylvania Department of Commerce.

Allen, D. and Levine, V. (1986), Nurturing Advanced Technology Enterprises: Emerging Issues in State and Local Economic Development Policy, New York, Prager.

Allen, D.N. and McCluskey, R. (1990), 'Structure, policy, services, and performance in the business incubator industry', Entrepreneurship: Theory and Practice 15 (2), 61-77.

Allen, D. N. and Rahman, S. (1985), 'Small business incubators: A positive environment for entrepreneurship', Journal of Small Business Management 23 (3), 12-22.

Al-Mubaraki, H.M. and Schrödi, H. (2012), 'Incubating success towards Gulf cooperation council (GCC)', International Journal of Innovation and Knowledge Management in Middle East and North Africa 1 (1), 31-56.

Al-Mubaraki, H.M. and Wong, S.F. (2011), 'How valuable are incubators? A case illustration of their performance indicators', European, Mediterranean \& Middle Eastern Conference on Information Systems 2011 (EMCIS2011), 30-31 May 2011, Athens, Greece, available at: http://www.iseing.org/emcis/EMCISWebsite/EMCIS2011\%20Proceedings/SIS2.pdf 
Amezcua, A.S. (2010), 'Performance analysis Of entrepreneurship policy: Which business incubators generate the highest levels of economic performance?, Frontiers of Entrepreneurship Research, 30 (18), 1-15

Ascigil, S.F. and Magner, N. R. (2009) 'Business incubators: Leveraging skill utilisation through social capital', Journal of Small Business Strategy 20 (1), 19-35.

Autio, E. and Klofsten, M. (1998), 'A comparative study of two European business incubators', Journal of Small Business Management 36 (1), 30-43.

Barbero, J. L., Casillas, J. C., Ramos, A. and Guitar, S. (2012), 'Revisiting incubation performance: How incubator typology affects results', Technological Forecasting and Social Change 79 (5), 888-902.

Barrow, C. (2001), Incubators: A Realist's Guide to the World's New Business Accelerators, Chichester, John Wiley and Sons Ltd.

Bearse, P. (1993), The Evaluation of Business Incubation Projects: A Comprehensive Manual, Athens, OH: The National Business Incubation Association.

Bergek, A. and Norrman, C. (2008), 'Incubator best practice: A framework', Technovation 28 (1/2), 20-28.

Birch, D.L. (1979), The Job Generation Process MIT Programme on Neighbourhood and Regional Change, Cambridge, MA: MIT.

BIS

(2012)

'Statistical

release',

available

at:

http://www.bis.gov.uk/assets/biscore/statistics/docs/b/bpe_2011_stats_release.pdf (accessed 30 ${ }^{\text {th }}$ May 2012).

Bøllingtoft, A. (2012), 'The bottom-up business incubator: Leverage to networking and cooperation practices in a self-generated, entrepreneurial-enabled environment', Technovation 32(5), 304-315.

Bøllingtoft, A. and Ulhøi, J.P. (2005), 'The networked business incubator-leveraging entrepreneurial agency?’, ,Journal of Business Venturing 20 (2), 265-290.

Brooks, O. (1986), 'Economic development through entrepreneurship: Incubators and the incubation process', Economic Development Review 4 (2), 24-29.

Brown, S.J. (2004), 'Minding and mining the periphery', Long Range Planning (37) 2, 143151. 
Brown, S.J. and P. Duguid (1998), 'Organizing knowledge', California Management Review $40(3), 90-111$.

Brown, S.J. and P. Duguid (2001), 'Knowledge and organisation: A social practice perspective', Organizational Science 12 (2), 198-213.

Bruneel, J., Ratinho, T., Clarysse, B. and Groen, A. (2012), 'The evolution of business incubators: Comparing demand and supply of business incubator services across different incubator generations', Technovation 32 (2), 110-121.

Bugliarello, G. (1998), 'Knowledge parks and incubators', in Dorf, R.C. (Ed.) The Handbook of Technology Management, Vol. 1, 41-49.

Buys, A. J. and Mbewana, P. N. (2007), 'Key success factors for business incubation in South Africa: The Godisa case study', South African Journal of Science 103 (9/10), 356358.

Cammarata, K. (2003), Self-Evaluation Workbook for Business Incubators, Athens, Ohio, NBIS Publications.

Campbell, C. (1989), 'Change agents in the new economy business incubators and economic development', Economic Development Review 7 (2), 56-59.

Campbell, C., Kendrick, R. C. and Samuelson, D.C. (1985), 'Stalking the latent entrepreneur: Business incubators and economic development', Economic Development Review 3 (2), 43-49.

Castells, M. and Hall, P. (1994), Technopoles of the World: The Making of the $21^{\text {st }}$ Century Industrial Complexes, London, Routledge.

Chan, K. F. and Lau, T. (2005), 'Assessing technology incubator programs in the science park: The good, the bad and the ugly', Technovation 25 (10), 1215-1228.

Chen, C-J. (2009), 'Technology commercialization, incubator and venture capital, and new venture performance', Journal of Business Research 62 (1), 93-103.

Colombo, M. G. and Delmastro, M. (2002), 'How effective are technology incubators? Evidence from Italy', Research Policy 31 (7), 1103-1122.

Connell, D. and Probert, J. (2010), 'Exploding the Myths of UK Innovation Policy: How 'Soft Companies' and R\&D Contracts for Customers Drive the Growth of the Hi-Tech Economy, Centre for Business Research, University of Cambridge, UK. 
Contu, A. and Willmot, H. (2000), 'Comment on Wenger and Yanow. Knowing in practice: A 'delicate flower' in the organizational learning field', Organization 7 (2), 269-276.

Contu, A. and Willmott, H. (2003), 'Re-embedding situatedness: The importance of power relations in learning theory', Organization Science 14 (3), 283-296.

Danilov, V. J. (1971), 'The research park shake-out', Industrial Research, 44-47.

Dee, N.J., Livesey, F., Gill, D. and Minshall, T. (2011), 'Incubation for growth: a review of the impact of business incubation on new ventures with high growth potential', NESTA, available

at: http://www.nesta.org.uk/library/documents/IncubationforGrowthv11.pdf

Dettwiler, P., Lindelöf, P. and Löfsten, H. (2006), 'Utility of location: A comparative survey between small new technology-based firms located on and off science parks implications for facilities management', Technovation 26 (4), 506-517.

Duff, A. (2000), 'Best practice in business incubator management', AUSTEP Strategic Partnering pty Ltd, available at: http://www.eifn.ipacv.ro/include/documentations_files/bestpracrpt.pdf (accessed $15^{\text {th }}$ January 2011).

Ebbers, J.J. (2013), 'Networking behavior and contracting relationships among entrepreneurs in business incubators', Entrepreneurship Theory and Practice, Early View, DOI: 10.111/etap.12032.

Entrepreneur

(2014),

Business

Incubator,

http://www.entrepreneur.com/encyclopedia/business-incubator

Eshun, J. P. (2009), 'Business incubation as strategy', Business Strategy Series 10 (3), 156166.

European Commission Enterprise and Industry (2010), 'Small and medium-sized enterprises

(SMEs) facts and figures', available at:

http://ec.europa.eu/enterprise/policies/sme/business-environment/failure-new

beginning/facts-figures_en.htm (accessed $18^{\text {th }}$ November 2010).

European Commission Enterprise Directorate General (2002), Benchmarking of Business Incubators, Brussels, Belgium: Centre for Strategy and Evaluation Services. 
Felsenstein, D. (1994), "University-related science parks: "seedbeds" or "enclaves" of innovation?', Technovation 14 (2), 93-110.

Ferguson, R. and Olofsson, C. (2004), 'Science parks and the development of NTBFs: Location, survival and growth', The Journal of Technology Transfer 29 (1), 5-17.

Fry, F.L. (1987), 'The role of incubators in small business planning', American Journal of Small Business 12 (1), 51-61.

Goldberg, A.I. and Lavi-Steiner, O. (1996), 'Developing an effective technological incubator: The experience of Israel', Industry and Higher Education 10, 371-376.

Gower, S. and Harris, F. (1996), 'Evaluating British science parks as property investment opportunities', Journal of Property Valuation and Investment 14 (2), 24-37.

Gower, S.M., Harris, F. C. and Cooper, P.A. (1996), 'Assessing the management of science parks in the UK', Property Management 14 (1), 30-38.

Grimaldi, R. and Grandi, A. (2005), 'Business incubators and new venture creation: An assessment of incubating models', Technovation 25 (2), 111-121.

Hackett, S.M. and Dilts, D.M. (2004), 'A systematic review of business incubation research', The Journal of Technology Transfer 29 (1), 55-82.

Hackett, S.M. and D.M. Dilts (2008). 'Inside the black box of business incubation: Study B scale assessment, model refinement, and incubation outcomes', The Journal of Technology Transfer 33, 439-471.

Hamilton, E. (2011), 'Entrepreneurial learning in family business: A situated learning perspective', Journal of Small Business and Enterprise Development 18 (1), 8 - 26

Hannon P. and Chaplin P. (2003), 'Are incubators good for business? Understanding incubation practice -- the challenges for policy', Environment and Planning C: Government and Policy 21 (6), 861-881

Hannon, P. (2005), 'Incubation policy and practice: building practitioner and professional capability', Journal of Small Business and Enterprise Development 12 (1), 57 - 75

Hansen, M.T., Chesbrough, H.W., Nohria, N. and Sull, D.N. (2000), 'Networked incubators: Hothouses of the new economy', Harvard Business Review 78 (5), 74-84.

Hansson, F. (2007), 'Science parks as knowledge organisations: The "ba" in action?', European Journal of Innovation Management 10 (3), 348-366. 
Hisrich, R.D. and Smilor, R.W. (1988), 'The university and business incubation: Technology transfer through entrepreneurial development', The Journal of Technology of Transfer 13 (1), 14-19.

Hoang, H. and Antoncic, B. (2003), 'Network-based research in entrepreneurship - A critical review', Journal of Business Venturing, 18 (2), 165-187.

Honig, B. and Karlsson, T. (2007), 'Social capital and the modern incubator: A comparison of in-group and out-group social networks', Frontiers of Entrepreneurship Research $27(15), 1-14$.

Hughes, M., Ireland, R. D., and Morgan, R. E. (2007), 'Stimulating dynamic value: Social capital and business incubation as a pathway to competitive success', Long Range Planning 40 (2), 154-177.

infoDev (2009), Annual Report, infoDev, http://www.infodev.org/highlights/infodev-2009annual-report-published (accessedL 20.10.2012).

Jack, S.L. and Anderson, A.R. (1999), Entrepreneurship education within the enterprise culture: Producing reflective practitioners', International Journal of Entrepreneurial Behaviour and Research 5 (3), 110-125.

Jones, O., Macpherson, A. and Thorpe R. (2010), 'Learning in owner-managed small firms: Mediating artefacts and strategic space', Entrepreneurship and Regional Development $22(7-8), 649-673$.

Kang, B-J. (2004), 'A study on the establishing development model for research parks', The Journal of Technology Transfer 29 (2), 203-210.

Karatas-Ozkan, M., Murphy, W.D. and Rae, D. (2005), 'University incubators in the UK', International Journal of Entrepreneurship and Innovation 6 (1), 401-421.

Ketchen, D.J., Thomas, J.B. and Snow, C.C. (1993), 'Organisational configurations and performance: A comparison of theoretical approaches', Academy of Management Journal 36 (6), 1278-1313.

Khalid F.A., Gilbert, D. and Huq, A. (2012), 'Third-generation Business Incubation Practices in Malaysian ICT Incubators-A Bridge Too Far?', American Journal of Management $12(2 / 3), 88-107$

Knopp, L. (2007), The State of the Business Incubation Industry, Athens, OH: NBIA. 
Kuratko, D.F. and LaFollette, W.R. (1987), 'Small business incubator for local economic development', Economic Development Review 5 (2), 49-55.

Lalkaka, R. (2001), "'Best practice" in business incubation: Lessons (yet to be) learned', European Union, Belgian Presidency International Conference on Business Centres: Actors for Economic and Social Development, Brussels, Belgium, 14-15 November.

Lalkaka, R. (2002), 'Technology business incubators to help build on innovation-based economy', Journal of Change Management 3 (2), 167-176.

Lalkaka, R. (2006), 'Technology business incubators: Critical determinants of success', Annals of the New York Academy of Sciences', 7 (8), 270-290

Lalkaka, R. and Bishop, J. (1996), Business Incubators in Economic Development: An Initial Assessment in Industrialising Countries, New York, United Nations Development Programme.

Lalkaka, R. and Shaffer, D. (1999), 'Nurturing entrepreneurs, creating enterprises and technology business incubation in Brazil', Proceedings of the International Conference on Effective Business Development Services, Rio de Janeiro, Brazil.

Lee, J.J., Kim, J.S. and Chun, H.K. (1999), 'Small business incubators: A positive environment for entrepreneurship', Journal of Small Business Management, 42(4), 418-426,

Lee, S.S. and Osteryoung, J.S. (2004), 'A comparison of critical success factors for effective operations of university business incubators in the United States and Korea', Journal of Small Business Management 42 (4), 418-426.

Lewis, D.A. (2001), Does Technology Incubation Work: A Critical Review of the Evidence, Washington, DC: US Department of Commerce Economic Development Administration.

Lewis, D.A., Harper-Anderson, E. and Molnar, L.A. (2011), Incubating Success Incubation Best Practice that Lead to Successful New Ventures, Michigan, University of Michigan.

Lichtenstein, G.A. (1992), The Significance of Relationships in Entrepreneurship: A Case Study of the Ecology of Enterprise in Two Business Incubator, Athens, OH: The National Business Incubation Association. 
Löfsten, H. and Lindelöf, P. (2002), 'Science parks and the growth of new technology-based firms-academic-links innovation and markets', Research Policy 31 (6), 859-876.

Lumpkin, J.R. and Ireland, R.D. (1988), 'Screening practices of new business incubators: The evaluation of critical success factors', American Journal of Small Business 12 (4), 5981.

Markley, D.M. and McNamara, K.T. (1995), 'Sustaining rural economic opportunity', American Journal of Agricultural Economics 7 (5), 1259-1265.

Marlow, S. and McAdam, M. (2012), 'Analyzing the influence of gender upon high technology venturing within the context of business incubation', Entrepreneurship Theory and Practice 4 (36), 655-676.

McAdam, M. and Marlow, S. (2007), 'Building futures or stealing secrets? Entrepreneurial cooperation and conflict within business incubators', International Small Business Journal 25 (4), 361-382.

McAdam, M. and McAdam, R. (2006), 'The networked incubator: The role and operation of entrepreneurial networking with the university science park incubator (USI)', International Journal of Entrepreneurship and Innovation 7 (2), 87-97.

Merrifield, D.B. (1987), 'New business incubators', Journal of Business Venturing 2 (4), 277-284.

Mian, S.A. (1996), 'Assessing value-added contributions of university technology business incubators to tenant firms', Research Policy 25 (3), 325-335.

Mian, S.A. (1997), 'Assessing and managing the university technology business incubator: An integrative framework', Journal of Business Venturing 12 (4), 251-285.

NBIA (1996), Business Incubation Works, OH: University of Michigan.

NBIA (2010), 'What is business incubation', available http://www.nbia.org/resource_library/what_is/ (accessed 10 $10^{\text {th }}$ March 2012).

NESTA (2008), 'Business incubation in challenging times,' available at: http://www.nesta.org.uk/assets/Uploads/pdf/Policybriefing/Business_incubators_PB3 0_NESTA.pfd (accessed 22 $2^{\text {nd }}$ December 2008).

Nowak, M. J., and Grantham, C. E. (2000), 'The virtual incubator: Managing human capital in the software industry', Research Policy 9 (2), 125-134. 
OECD (1999), Business Incubation International Case Studies, Paris, OECD Publications.

OECD (2010), High-Growth Enterprises-What Governments Can Do to Make a Difference, Paris, OECD Publications.

Patton, D., Warren, L. and Bream, D. (2009), 'Elements that underpin high-tech business incubation processes', The Journal of Technology Transfer 34 (6), 621-636.

Peters, L., Rice, M. and Sundararajan, M. (2004), 'The role of incubators in the entrepreneurial process', The Journal of Technology Transfer 29 (1), 83-91.

Phan, P.H., Siegel, D.S. and Wright, M. (2005), 'Science parks and incubators: Observations, synthesis and future research', Journal of Business Venturing 20 (2), 165-182.

Phillips, R. (2002), 'Technology business incubators how effective as technology transfer mechanisms?', Technology in Society 24 (3), 299-316.

Plosila, W.H. and Allen, D.N. (1985), 'Small business incubators and public policy: Implications for state and local development strategies', Policy Studies Journal 13 (4), 729-734.

Reid, S. and Garnsey, E. (1997), 'The growth of small high-tech-firms: Destinies and destinations of innovation centre graduates', New Technology, Work and Employment $12(2), 84-90$.

Rice, M. P. (2002), 'Co-production of business assistance in business incubators: An exploratory study', Journal of Business Venturing 17 (2), 163-187.

Roberts, J. (2006), 'The limits of communities of practice', British Journal of Management, 43 (3), 623-639.

Rothaermel, F.T. and Thursby, M. (2005) 'The nanotech versus the biotech revolution: Sources of productivity in incumbent firm research', Research Policy 36 (6), 832-849

Rothschild, L. and Darr, A. (2005), 'Technological incubators and the social construction of innovation networks: an Israeli case study, Technovation 25, 59 - 67.

Rouach, D., Louzoun, S. and Deneux F. (2010), Incubators of the World Best Practices from Top Leaders: USA, Israel, France, Switzerland China and Japan, France, Pearson Education.

Roure, J. (1997), 'Ten myths about entrepreneurs'. In Birley, S. and Muzyka, D. F. (Eds) Mastering Enterprise, London, FT Pitman Publishing. 
Schwartz, M. (2011), 'Incubating an illusion? Long-term incubator performance after graduation', Growth and Change 42 (4), 491-516.

Schwartz, M. and Göthner, M. (2009), 'A multidimensional evaluation of the effectiveness of business incubators: An application of the PROMETHEE outranking method', Environment and Planning and Government and Policy 27 (6), 1072-1087.

Schwartz, M. and Hornych, C. (2008), 'Technologie- und Gründerzentren im Lichte von Diversifizierung versus Spezialisierung', IWH Discussion Papers 7, Halle Institute for Economic Research.

Sherman, H.D. (1999), 'Assessing the intervention effectiveness of business incubation programmes of new business start-ups', Journal of Developmental Entrepreneurship $4(2), 117-133$.

Smilor, R.W. (1987), 'Commercialising technology through new business incubators', Research Management 30 (5), 36-41.

Smilor, R.W. and Gill, M.D. (1986), The New Business Incubator Linking Talent, Technology, Capital, and Know-how, Massachusetts, Lexington Books.

Sondakh, D.F. and Rajah, K.K. (2006), 'Developing an entrepreneurial culture', Entrepreneurship and Innovation 7 (4), 231-241.

Squicciarini, M. (2009), 'Science parks: Seedbeds of innovation? A duration analysis of firms’ patenting activity', Small Business Economics 32 (2), 169-190.

Storey, D.J. (1994), Understanding the Small Business Sector, London, International Thomas Business Press.

Suk, J.Y., and Mooweon, R. (2006), 'Resource mobilization and business incubation: The case of Korean incubators', Development and Society 35, 29-46.

Temali, M. and Campbell, C. (1984), Business Incubator Profiles: A National Survey, Hubert Humphrey Institute of Public Affairs, University of Minnesota, Minneapolis.

Theodorakopoulos, N., Ram M. and Beckinsale M. (2013), 'Developing Large Procurers and Ethnic Minority Business Owners for Supplier Diversity', International Journal of Human Resource Management 24 (12), 2321-2338. 
Theodorakopoulos, N., Sanchez, D. and Bennett, D. (2012), 'Transferring Technology from Academia to Rural Industry within a Developing Economy Context: The Case for Nurturing Communities of Practice', Technovation 32 (9-10), 550-559.

Timmons, J.A. (1994), New Venture Creation: Entrepreneurship for the $21^{\text {st }}$ Century, Burr Ridge, IL, Irwin Press.

Tötterman, H. and Sten, J. (2005), 'Start-ups: Business incubation and social capital', International Small Business Journal 23 (5), 487-511.

Udell, G.G. (1990), 'Are business incubators really creating new jobs by creating new businesses and new products?', Journal of Product Innovation Management 7 (2), 108-122.

UKBI (2004), The National Business Incubation Framework, Birmingham, UK Business Incubation.

UKBI (2009), The Business Incubation Development Framework, Birmingham, UK Business Incubation.

UKBI (2012), Best Practice in Business Incubation, Birmingham, UK Business Incubation.

URS (2010), 'The City's role in providing for the public equity financing needs of the UK

SMEs', available at:

http://www.strath.ac.uk/media/departments/huntercentre/research/researchreports/Co

L-URS_final_report.pdf (accessed 20 June 2011).

van Tilburg, J., van der Sijde, P., Molero, J. and Casado, P. (2002), 'Virtual incubation research spin-offs', The international Journal of Entrepreneurship and Innovation 3 (4), 285-293.

Vanderstraeten, J., Witteloostuijn, V. A., Matthyssens, P., and Andreassi, T. (2011), 'Business incubator performance in Brazil: The influence of service focus, service customization and the cognitive institutional context', 2nd Annual ICSB.

Voisey, P., Gornall, L,. Jones, P. and Thomas, B. (2006), 'The measurement of success in a business incubation project', Journal of Small Business and Enterprise Development 13 (3), 454-468.

Wadhwani Foundation (2013), Guidelines for Metrics and Milestones for Successful Incubator Development, New National Entrepreneurship Network, April, 
http://nenglobal.org/wpcontent/uploads/2014/03/Guidelines for Metrics and Milestones for Incubators.pdf

Wenger, E. (1998), Learning, meaning and identity, New York, Cambridge University Press.

Wenger, E. (2000), 'Communities of practice and social learning systems', Organization 7 (2), $225-246$.

Wenger, E. (2010), 'Conceptual tools for CoPs as social learning systems: Boundaries, identity, trajectories and participation'. In Blackmore, C. (ed.), Social Learning Systems and Communities of Practice, Milton Keynes, Springer/The Open University, $125-143$.

Wenger, E., McDermott, R. and. Snyder, W.M. (2002), Cultivating communities of practice. Boston, MA, Harvard Business School Press.

Westhead, P. (1997), 'R\&D "inputs" and "outputs" of technology-based firms located on and off science parks’ $R \& D$ Management 27 (1), 45-62.

Westhead, P., and Batstone, S. (1999), 'Perceived benefits of a managed science park location', Entrepreneurship and Regional Development 11 (2), 129-154.

Wiggins, J., and Gibson D.V. (2003), 'Overview of US incubators and the case of the Austin Technology Incubator', International Journal of Entrepreneurship and Innovation Management, 3 (1/2), 56-67.

Williamson, O.E. (1975), Markets and Hierarchies: Analysis and Antitrust Implications, New York, NY, The Free Press. 